\title{
MIMMARLIKTA ESTETİK DEĞERLENDİRME: ULUSAL TEZLER ÇERÇEVESINDE SORGULAMA
}

\author{
Mehmet Fetullah Özyıldırım¹, Pınar Dinç Kalaycı
}

\section{Özet}

Baumgarten'den bu yana bilim olma çabası içinde olan estetik konusu, geçmişinde metafiziksel bir anlam yüklenen kavram iken artık birçok bilimsel çalışmanın altında yer almaktadır. Sanat ve bilim arasında sıkışan mimarlık disiplini, var olduğundan beri estetik konusunda bir arayış içindedir. Çalışmanın amacı, son yıllarda yapılan tez çalışmalarında adına sıkça rastladığımız estetik konusunun mimarlık disiplini ile nasıl ilişkilendiği tespit etmektir. Çalışma kapsam olarak ulusal yök tez merkezinde yayınlanan tezlerin mimarlık ve estetik etiketleri ile sınırlandırılarak elde edilen 312 tezin incelenmesinden oluşmaktadır. Elde edilen verilere göre, en fazla çalışmasının 2019 senesine ait olan estetik konusunun, mimarlık ile olan ilişkisi genellikle dönemsel mimari eserlerin ve mekan kavramının algısal ve biçimsel analizlerinden oluşmaktadır.

Anahtar Kelimeler: Mimarlık, Estetik, Tez, Disiplinler Arası Etkileşim, Dökümantasyon

\section{AESTHETIC EVALUATION İN ARCHITTECTURE: STUDY İN THE FRAMEWORK OF NATIONAL THESES}

\begin{abstract}
The subject of aesthetics, which has been trying to be a science since Baumgarten, is a concept that has a metaphysical meaning in the past, but now it is under many scientific studies. The discipline of architecture, which is stuck between art and science, has been in search of aesthetics since its existence. The study aims to determine how the subject of aesthetics, which we have frequently encountered in thesis studies in recent years, is related to the discipline of architecture. The scope of the study consists of examining 316 theses obtained by limiting the architectural and aesthetic labels of the theses published on the national thesis platform. According to the data obtained, the relationship between the aesthetic subject of 2019, which is the most of its work, and architecture generally consists of perceptual and formal analyzes of periodical architectural works and the concept of space.
\end{abstract}

Keywords: Architecture, Aesthetic, Thesis, Interdisciplinary Interaction, Documentation

\footnotetext{
${ }^{1}$ Arş. Gör., Gazi Üniversitesi, Mimarlık Fakültesi, Mimarlık Bölümü, ORCID ID: 0000-0002-34079488, mfozyildirim@gazi.edu.tr

${ }^{2}$ Prof. Dr., Gazi Üniversitesi, Mimarlık Fakültesi, Mimarlık Bölümü, ORCID ID: 0000-0002-19329477,pdinc@gazi.edu.tr
} 


\section{MIMMARLIKTA ESTETIKK DEĞERLENDİRME: ULUSAL TEZLER ÇERÇEVESİNDE SORGULAMA}

\section{Giriş}

Tunalı (1998), estetik ifadesinin 18.y.y. kadar metafiziksel bir anlam taşıdığını Baumgarten'nin yayımladığı 'Aesthetica' kitabıyla bilimsel bir ifade olarak tartışılmaya başlandığını dile getirir.

Tunalı (1998), güzelin güzel olması için bazı niteliklere sahip olması gerektiğini dile getirir. Güzel olanın belirli bir tipi olmalı, hangi türe ait ise o türü genellemeleri içinde olmalıdır. Güzel olanın cinsine uygun olması beklenir. Örneğin bir atı göz önüne alırsak hörgüçlü bir at çirkin olurdu.

Vitruvius (2005), ustaların binayı yapım ilkelerine göre inşa ederken mimarları da binanın çirkin olmasını engellemek için çeşitli oranlar, harmoni ve renkler kullanarak güzel görünmesi sağladığını dile getirir. Mimarın yapıya estetik doygunluk kazandırması için 'sağlam, kullanışlı ve güzel' kavramlarını dengeli şekilde kullanarak inşa etmesi gerektiğini söyler.

Sanatçı vermek istediği mesajı eserinde yarattığı biçim ile anlatır. Nasıl sanatta sanatçı-sanat-toplum ilişkisi var ise mimarlıkta ise bu durum mimar-yapıt-toplum olarak var olur. Mimarlıkta verilmek istenen mesaj malzemeye verilen biçim ile elde edilir. Bu durumda biçim özü yansıtmaya başlar (Timuçin, 2017).

Çalışmanın amacı, son yıllarda yayınlanan araştırmalarda adına sıkça rastladığımız estetik konusunun mimarlık disiplini ile nasıl ilişkilendiğini tespit etmektir.

Çalışma kapsamı, yök tez merkezinde yer alan ulusal tezlerin özet kısmında 'estetik' ve 'mimarlık' ifadesi geçen 312 tezlerden oluşmaktadır. Çalışma, ilk yayın yılının 1984'ten günümüze kadar olan tüm tezleri içermektedir.

Çalışma aynı zamanda onar yıllık arayla elde edilen tezleri kıyaslayarak, estetik konusunun mimarlık alanında ne noktalara geldiğini de tespit etmektedir. Çalışma da yöntem olarak, 3 farklı zaman dilimini karşılaştırarak analiz yapılmaya çalışılmıştır. Bu yaklaşım yöntemi total analiz yapmayı sağlarken estetik konusun nereden başlayıp ne noktaya geldiğini, hangi zaman diliminde hangi konuların daha çok çalışıldı ğını da tespit etmektedir.

\section{Estetik}

Estetik kelimesi yunanca kökenli olup 'aisthanesthai' kelimesinden türemiştir. Osmanlıca dilinde 'ilmi zevk' anlamına gelen bu kelime, Hegel için güzellik bilimi olarak da ifade edilmiştir (Ergün, 2020).

Ergün (2020), yaptığı çalışmada estetik konusunun Baumgarten'den sonra alman filozof İ. Kant'in bu konuya önem vermesiyle felsefe alanında hizlı bir 


\section{MIMMARLIKTA ESTETIKK DEĞERLENDİRME: ULUSAL TEZLER ÇERÇEVESINNDE SORGULAMA}

ivmelenme kazandığını ifade eder. Kant, 'Güzel, 'İyi', ‘Doğru' ifadeleri sorgulayarak estetik terimi bilimsel olarak incelemiştir.

Erş (2005), çalışmasında Kant'ın güzelden çıkar beklenilmeden hoşa gidilmesi gerektiğini, Hegel'in güzelin tinde var olduğunu, Nietzche'nin güzel ile doğrunun aynı şey olmadığını ve Heideger'in özde olan biçimsel özellikler olduğunu dile getirir.

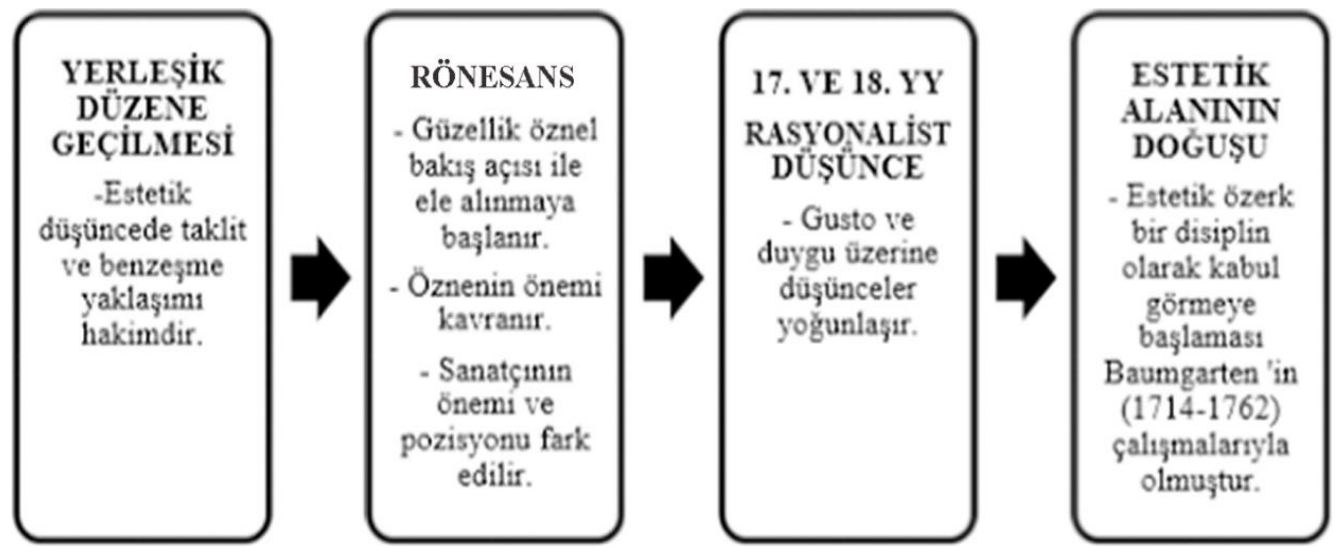

Resim 1: Estetik tarihinin gelişimi (Yılmaz, 2018).

Bilim, problemleri formüle ve sistematik hale getirip çözmeye çalışırken estetik gibi nitel konularda farklı bir yöntem izleyerek analiz etmeye çalışır (Ergün, 2019).

Doğan (1975), estetiğin yöntem sorunun her zaman tartışma konusu olduğunu, yöntem sorunun ortaya çıkmasının ana sebebinin sanat bilimi olarak ele alınması olduğunu söylemektedir. Estetik konusunu inceleyecek ana bir yöntemin olmadığını çalışılan her yöntemle daha da zenginleşebileceğini dile getirmektedir.

\section{Estetik alg1}

Tunalı (1998), alg1 kavramını nesnenin üzerimizde bıraktığı etki olarak ifade eder. Bizlere söylenen herhangi bir nesnenin (masa, bardak) var olan bilgilerimizle karşılaştırıp, onun üzerimizde bıraktığı duygusal bağı duyumsadığımızı, bu duyumsamaların ise gerçek olan olduğunu dile getirir.

Yücel (2011), tez çalışmasında bilginin algıyı etkilediğini ifade eder. Yapılan çalışma da ekoloji konusunda ders alan öğrencilerin ekolojik binaları daha fazla beğendi sonucunu ortaya koymuştur.

\section{Estetik yarg1}

Ergün (2019), estetik yargıyı nesneler hakkında haz ve beğeni konusunda ortaya koyduğumuz sübjektif hükümler olarak nitelendirmektedir. Ortak bir estetik 


\section{MIMMARLIKTA ESTETIKK DEĞERLENDİRME: ULUSAL TEZLER ÇERÇEVESİNDE SORGULAMA}

yargının olup olmayacağı tarih boyunca süre gelen bir tartışma konusudur ve bu konuda fikir ayrılıklarına düşen birçok düşünür mevcuttur.

Estetik yargının ortak bir paydada buluşamamasının ana nedenlerinden biri bağlı olduğu değişkenlerinde sübjektif olmasıdır. Estetik yargı topluma, kültüre, geleneklere, bireysel deneyimlere ve daha nice kişiden kişiye değişebilir olan disiplinlere bağlıdır.

Birçok sanat eserinin döneminde incelenmesi ile ortaya çıkan estetik kriterler o dönemin beğeni anlayışını anlamamıza yardımcı olur. Bu yöntem bizleri iyi-kötü, güzel-çirkin sıkalasından çıkarıp daha öznel bir ifade kullanmamızda yardımcı olur. Örneğin 'naiflik' ifadesi estetik bir kriter olarak kullanıldığında daha bilimsel bir veri elde edilmiş olacaktır (Timuçin, 2017).

Ergün, (2019) Baumgarten'in estetik yargının genellikle zamana ve mekana bağlı olarak değişebildiğini ancak bir genelleme söz konusunu olduğunda estetik bir değer kazandığını dile getirir. Örneğin birçok çalışması beğenilen sanatçının ismine ithafen eserleri güzeldir denmesi genel geçerliliği olan bir yargıdır.

\section{Estetikte 'özne' ve 'nesne'}

Estetik yargı özne ile nesnenin etkileşim içinde olması sonucu oluşur. Estetik bir yargı oluşumunda nesnenin rolü fiziksel özelliklerine bağlı iken özne daha duygusal bir rol oynamaktadır. Birçok kuramcı bu duruma 'estetik deneyim' de demektedir (Tekel, 2015).

Tekel (2015), Winston ve ekip arkadaşının yaptığı çalışmada estetik deneyim sürecinde dört aşamadan geçtiğini belirtir. Bunlardan ilkinde birey kendisiyle ve inançlarıyla olan ilişkisine bakar. İkinci aşamada gerçekliğine değer verir. Üçüncü süreçte nesnenin oluşum süreciyle empati kurar. Son olarak da biçimine ve stiline odaklanir.

Estetik, nesnenin rolünü fiziksel özelliklere bağlı olarak ele almaktadır. Kuramcilar genel olarak bu konuda ikiye ayrılmıştır. Güzelin özden kaynaklı olduğunu, ideyi en iyi yansıtan nesnenin güzel olduğunu savunanlar 'içsel nitelikçiler', ya da nesnenin oran, harmoni, uyum gibi biçimsel özelliklerini savunan 'dışsal nitelikçiler' (Ergün, 2019).

Estetikte öznenin rolü duyulara iyi geliyorsa güzel olduğudur. Duygular üzerinden değerlendirmeye önem verilir. Duygunun estetik ile olan ilişkisi incelendiğinde duygunun öğretilebilir olduğu ve kültürlere bağlı olduğu görülmektedir. Birey yaşam içinde aldığı eğitim estetik beğenisine etki etmektedir. Bireyin bağlı olduğu toplumun değerleri (örf, adet, inanç..) yine estetik beğeniye etki etmektedir (Eaton, 1995). 


\section{MIMMARLIKTA ESTETIKK DEĞERLENDİRME: ULUSAL TEZLER ÇERÇEVESİNDE SORGULAMA}

\section{Biçim}

Masiero (2006) insanlık tarihinin estetik anlayışını incelerken ilk mimari yapılarda birebir doğayı taklit etme çabası olduğunu dile getirir. İlkel insanların barınma alanlarından sonra estetik bir kaygı güderek inşa ettikleri ilk yapıların tapınaklar olduğunu ve bu konuya en fazla önem verenlerin ise yunan toplumu olduğunu ifade eder. Yunan mimarlığında estetik kriter olarak; 'kanon, ölçek, düzen, simetri, ritim' beşlisi ele alınırdı.

Estetik kavramının bilim olma çabası ile ele alınan analizler sonucunda yeni kavramlar türemiştir. Bunlar kısaca; büyüklük, güç, naif, ardışık, birim..vb kavramları estetik bir analiz için daha öznel veriler elde etmemize yardımcı olmuştur. Daha sonraları yapılan çalışmalarla güzel olan şeyin çevresiyle ve içeriğiyle bir bütün içinde çalışılması gerektiği, sadece biçim üzerinden çalışılmanın mimarlığı kısırlaştırdığı, güzelin sosyal, psikolojik, tarihsel durumlara da bağlı olduğu savunulmaya başlanmıştır (Yılmaz, 2018).

Biçimin insanlar üzerinde psikolojik etkileri vardır. yaratılmak istenen algıda bu psikolojik deneyimlerden yardım alınarak mekanlar yaratılır. Örneğin; açık mekanların 'güven', kubbe gibi yapıların 'toplayıc1', hareketli cephelerin 'enerjik' bir hava verir. Biçimi ifade ederken onu oluşturan objeleri ele alırsak daha analitik bir yaklaşım elde etmiş oluruz. Biçimi oluşturan etmenleri, 'ölçek, oran, renk, doku, ses, dolu-boş, uyum, 1şık, birim-birlik' olarak ele alabiliriz (Becerik, 2001).

\section{Mimarlıkta estetik}

Mimarlık disiplinin sanat ile olan ilişkisi diğer disiplinlere göre farklıdır. Örneğin resim ya da müzik gibi sanat ile doğrudan ilişkili olan disiplinlere baktığımız da sanatça eserini 'sanat, sanat içindir' savını öne sürerek tuvalini gönlünce düzenleyebilir. Ancak mimarlık tanımı gereği bağlamlara sahiptir. İşlevsiz bir eser mimarlık disiplini altında tartış1lamaz (Kuban, 2018).

Nevzat Sayın'ın sunuculuğunu yaptığı, Doğan Tekeli' in konuk olduğu 'MiM' programında Tekeli, fotoğrafların aldatıcı olduğunu, fotoğraflarına bakıp hayranlık duyduğumuz binaların yerinde görüldüğünde hayal kırıklığına uğrattı̆̆ını dile getirmektedir (Youtube.com, 2021). Mimari yapılar devasa ölçekte olan 3 boyutlu yapılardır. Dolasıyla 2 boyuta sığdırdığımız fotoğraflarla bina yaşantısına dahil olmadan yeterince anlayamayız. Bu yüzden algı üzerine yapılan çalışmalarda binaların fotoğraflar üzerinden değerlendirilmesi her zaman eksik kalır.

Estetik kriterlerin arayışında olan Becerik (2001), çalışmasında estetik kriterlerin bireysel tercihlerle değil toplumsal tercihler sonucunda tespit edildiğini 


\section{MIMARLIKTA ESTETIKK DEĞERLENDİRME: ULUSAL TEZLER ÇERÇEVESİNDE SORGULAMA}

dile getirir. Toplum tarafından benimsenen biçimler, yere ve zamana göre değişkenlik gösterebilir, birer estetik kriter oluşturur.

Mimari yapılar hiçbir zaman estetik kaygılardan sıyrılarak var olamamıştır. Hatta biçimin işlevi takip etmesi gerektiğini iddia eden görüşler bile aslında birer estetik çözüm arayışındalar. Mimarlık disiplinin birçok alt başlığı vardır ve insanlık gelişim gösterdikçe de bu alt başlıkların sayısı da gittikçe artacaktır. Mimarlık disiplinin altında olan ana başlıların estetik ile olan ilişkisinin incelendiği bu çalışmada tabloya dökülen çalışmaların mimarlığın hangi alt disiplinin estetiğin hangi alt disiplini ile çalışıldığ tespit edilmeye çalışılmıştır.

Estetik konusunun hangi mimarlık alt disiplini ile çalışıldığının listesi;

- Bilișim: gelişen teknoloji ile mimarlık dalında edinilen alışkanlıklarda değişti. Örneğin öncesinde el ile çizim ile yapilırken şimdilerde bilgisayar ortamındaki cad programları sayesinde bu süreç çok hızlı ve kaliteli bir şekilde yürütülmektedir. Cad programları sayesinde analiz etme ve programlamanın daha kapsamlı olması sayesinde birçok yeni biçimler elde edilmektedir. Yüksek teknolojiyle inşa edilen birçok yapının temelinde bu programlar yatmaktadır. Modelleme dünyasında yapılacak olan binanın daha inşa edilmeden nasıl bir alg1 yaratacağını da öncesinden anlayabiliyoruz.

- Biyomimesis: Kelime anlamiyla tekrar anlamina gelen mimesis ifadesi, biyomimesis kavramı olarak ifade ettiği şey yeryüzünde yaşan canlıların, mimarlığa referanslar sunduğunu anlamına gelir. Örneğin yer altında yaşan karıncaların yer altında yapılacak olan bir binaya referans niteliğinde bilgiler verebilir (Selçuk ve Sorguç, 2007).

- Cephe: Hasol'un (1979) binanın herhangi bir yüzü olarak tanımladığı, mimarlığın görünen yüzü olarak ifade edebileceğimiz cephe kavramı,

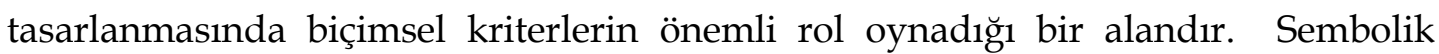
anlamlar yüklediğimiz biçimlerin genellikle yer aldığı yüzey cephedir. Cepheler, kentsel bir doku olarak ele alındığında kentin karakteristik yüzünü oluşturur. Kent silüetleri genellikle bina cephelerinden oluşur. Biçim girdisinin cephede bu kadar değerli olması dışavurumun en fazla olduğu yüzey olmasındandır.

- İslev: Fonksiyon olarak da ifade edebileceğimiz bu kavram $\llcorner$ bir binanın işleyiş ve kullanışlılık bakımından hangi amaca uygun hizmet ettiğinin tanımıdır (Hasol, 1975). Bir yapı formunun işlevine çok uygun tasarlanması sonucun da tipoloji oluşur. Örneğin kubbeli yapı biçimi camii işlevini hatırlatırken, karakteristik türk evlerinde de olan yapı elemanları ve sistemleri de tipoloji oluşturur.

- Kuram: Teori. Düşünce ifadesi. Bir problemin ifade edilmesine ya da çözüm üretilmesine yönelik ilgilenilen bilgi ve bu bilginin temelleridir (Hasol, 1975). Örneğin, estetik konusunun var oluş temellerini ve bilgi birikimini inceleyen düşünce tarzıdır. 


\section{MIMMARLIKTA ESTETIKK DEĞERLENDİRME: ULUSAL TEZLER ÇERÇEVESINNDE SORGULAMA}

- Mekan: İnsanın eylemlerini gerçekleştirmesi için, oluşturulan boşluklar olarak ifade edebiliriz. Mimarlıkta iç mekân ve kentsel mekan ifadelerinin anlamına bakınca iç mekan için bina kütlesinin içinde yarattığı boşun iken kentsel mekandan kasıt binaların kendi aralarında oluşturmuş olduğu parklar, sokaklar olarak tanımlayabiliriz (Hasol, 1975).

- Stil mimarlığı: Belirli bir üslup oluşturmuş mimarlardır. Kendine has çizgiler oluşturan mimarların eserlerinden öte kendilerinin incelenmesidir. Örneğin Zaha Hadid kullandığı amorf ve devasa kütlelerle kendine has üslubunu ortaya koyması gibi. Yaptığ1 eserlerden ötürü yapacağı eserlerin tahmin edilebilir olması mimarın bir stilinin olduğunu gösterir.

- Sürdürülebilirlik: Herhangi bir olayın süregelen, devridaim, daimi olmas1 için oluşturulan yöntem. Mimarlığa olan yansıması çevre bilincinin oluşmasından sonra çevreye yayılan karbon ayak izinin azaltılmasına yönelik çalışılan yöntemlerdir. Ekoloji ifadesini de barındıran bu kavram ile enerji konusunda binaların rolünü inceleyip bu bağlam çerçevesinde tasarlanmasıdır.

- Dönem mimarlığg: Geçmiş dönemlerde var olan mimari eserlerin anlamlandırılmasıdır. Günümüz ve geleceğe yönelik mimarlığın dışında kalan geçmiş zaman döneminde üretilen tipoloji, düşünce ya da eserlerin kapsamıdır.

\section{Materyal, yöntem ve bulgular}

Çalışmada, yök tez platformunda yayınlanan tezlerin estetik ve mimarlık disiplinlerinin hangi alt başlıkları ile çalışıldığı analiz edilerek tablolar oluşturulmuştur. Bu tablolara göre estetik konusu 'estetik, alg1, yarg1, özne-nesne, biçim' alt başlıklarına ayrılırken mimarlık ise 'bilişim, biyomimesis, cephe, dönem mimarlığı, işlev, kent, kuram, mekan, stil mimarlığı, sürdürülebilirlik ve yapım sistemleri' alt başlıklarına indirgenmiştir. Çalışma sayısının az olmasından dolayı 2000 senesinden önceki tezleri bir periyot, 2000 ve 2010 arasi yayınlanan tezleri bir periyot ve 2010 senesi ve sonrası yayınlanan tezleri de bir periyot olarak ele alarak 3 farklı zaman diliminde inceleme yapılmıştır.

Çalışma yöntemi, yök tez platformundaki yayınlanan tezleri estetik ve mimarlık disiplinlerinin hangi alt başlıkları ile çalışıldığını analiz ederek tablo oluşturmaktır. Bu tabloya göre estetik konusu 'estetik, alg1, yarg1, özne-nesne, biçim' alt başlıklarına ayrılırken mimarlık ise 'bilişim, biyomimesis, cephe, işlev, kuram, mekan, stil mimarlığı, sürdürülebilirlik, dönem mimarlığı' alt başlıklarına indirgenmiştir.

\section{0 'den öncesi}




\section{MIMARLIKTA ESTETIKK DEĞERLENDİRME: ULUSAL TEZLER ÇERÇEVESINNDE SORGULAMA}

Yapılan araştırmaya göre 2000 öncesi yayınlanan tez sayısı 52' dir. Bu kapsam içerisinde 2000 senesinin yayınları dahil edilmemiştir. Tez sayıların ve türlerinin çizildiği tablolarda 52 tezin tamamı dahil edilmiştir. Ancak yapılan tez incelemelerinde bu tezlerden 4 tanesinin mimarlık ve ya estetik ile ilgili olmadığ 1 tespit edilmiştir. Dolayısıyla estetik ve mimarlık konu başlıklarının altında çizilen tablolarda incelemeye alınan tez sayısı $48^{\prime}$ dir.

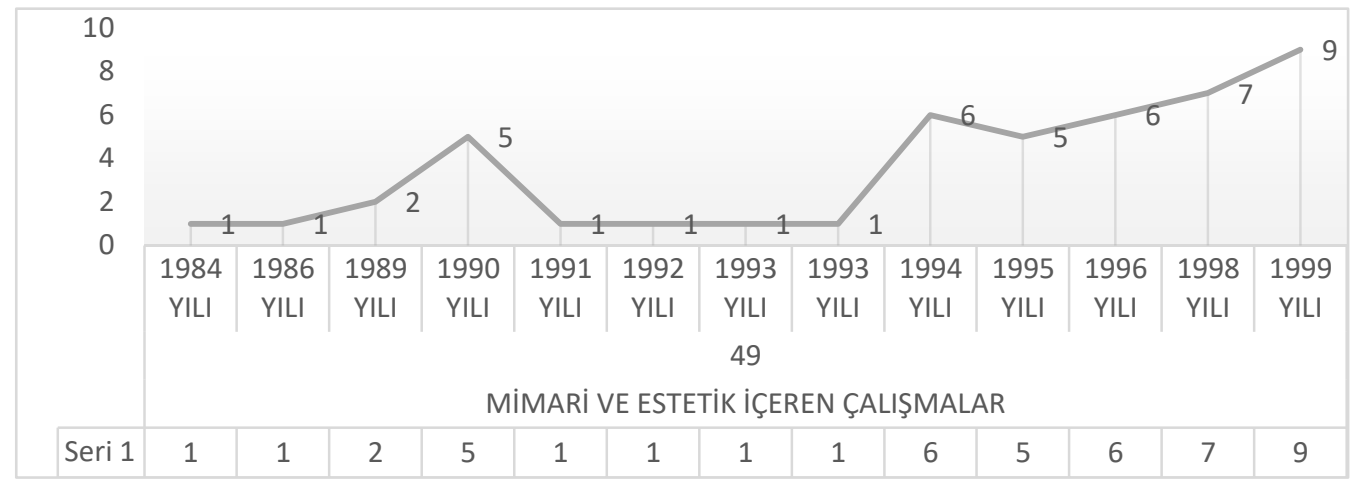

Tablo 1: 2000 öncesi tez çalışmalarının yıllara göre dağılımı

Tablo 1'e göre 2000 öncesinde yayınlanan ilk tez 1984 senesinde doktora tezidir. 1989 yılına kadar tüm yayınlar doktora tezidir. Yine ilk yüksek lisans tezi 1989 yılında yayınlanmıştır. En fazla yayın yapılan yıl ise 9 tez sayısı ile 1999 senesidir. 1999 senesinde yayınlanan tezin tümü yüksek lisans tezidir. İlk senelerde grafikte belirli bir yükseliş görünmese de son 5 sene içerisinde grafikte istikrarlı bir artış görülmektedir.

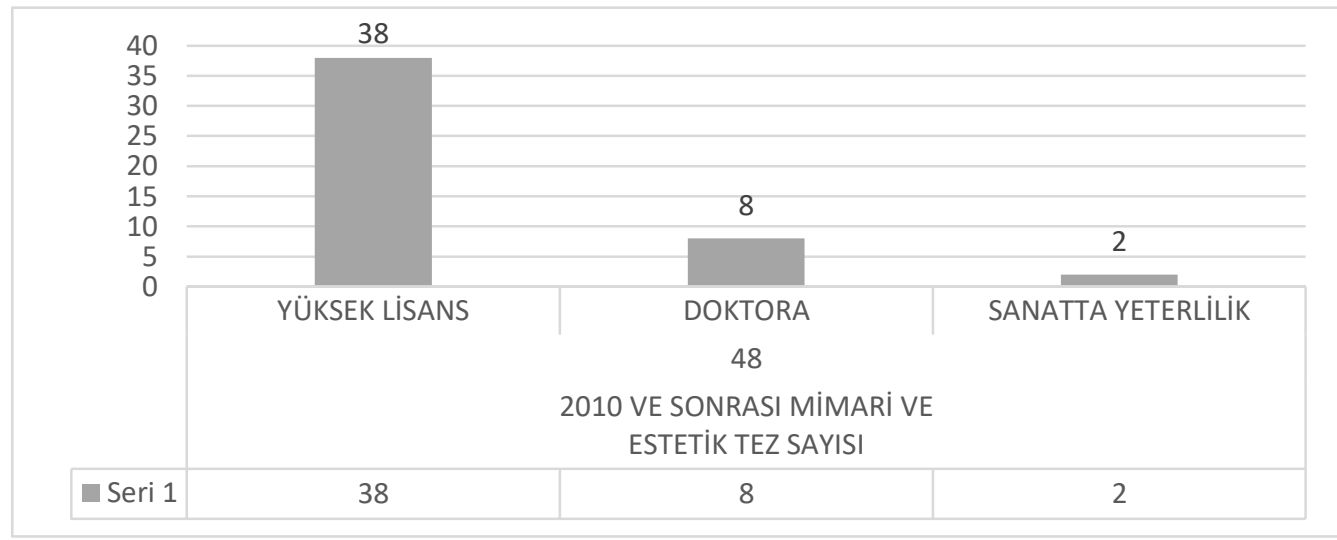

Tablo 2: 2000 öncesi tez çalışmalarının yayın türüne göre dağılımı 


\section{MIMMARLIKTA ESTETIKK DEĞERLENDİRME: ULUSAL TEZLER ÇERÇEVESINNDE SORGULAMA}

Tablo 2'ye bakıldığında 2000 öncesi yayınlanan tezlerin ilk 3 senesinin tamamı doktora tezi olmasına rağmen son senelerde yayınlanan yüksek lisans tez sayısının artması ile en fazla yayın yapılan tez türü 38 tez sayısı ile yüksek lisans tezleridir.

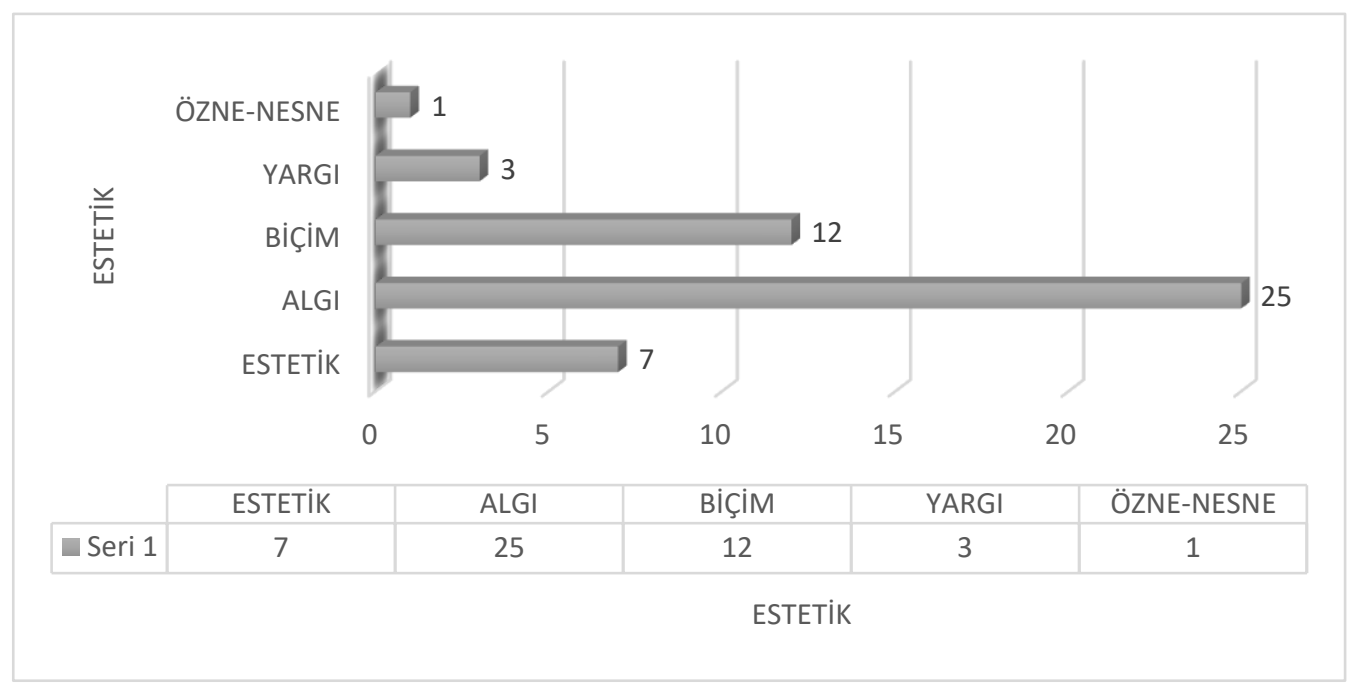

Tablo 3: 2000 öncesi tez çalışmalarının estetik konusun alt başlıklarına göre dağılımı

Tablo 3'te estetik konusun alt başlılarına göre dağılımı görülmektedir. Bu tabloya göre 48 tezden en fazla çalışma yapılan konu algıdır. En az çalışılan konu ise 'özne-nesne' dir. 7 çalışma ise estetik konusunun genel yaklaşımı içerisinde çalışma yapmıştır dolayısıyla bir alt başlığa indirgenememiştir. 
MIMARLIKTA ESTETİK DEĞERLENDİRME: ULUSAL TEZLER ÇERÇEVESINNDE SORGULAMA

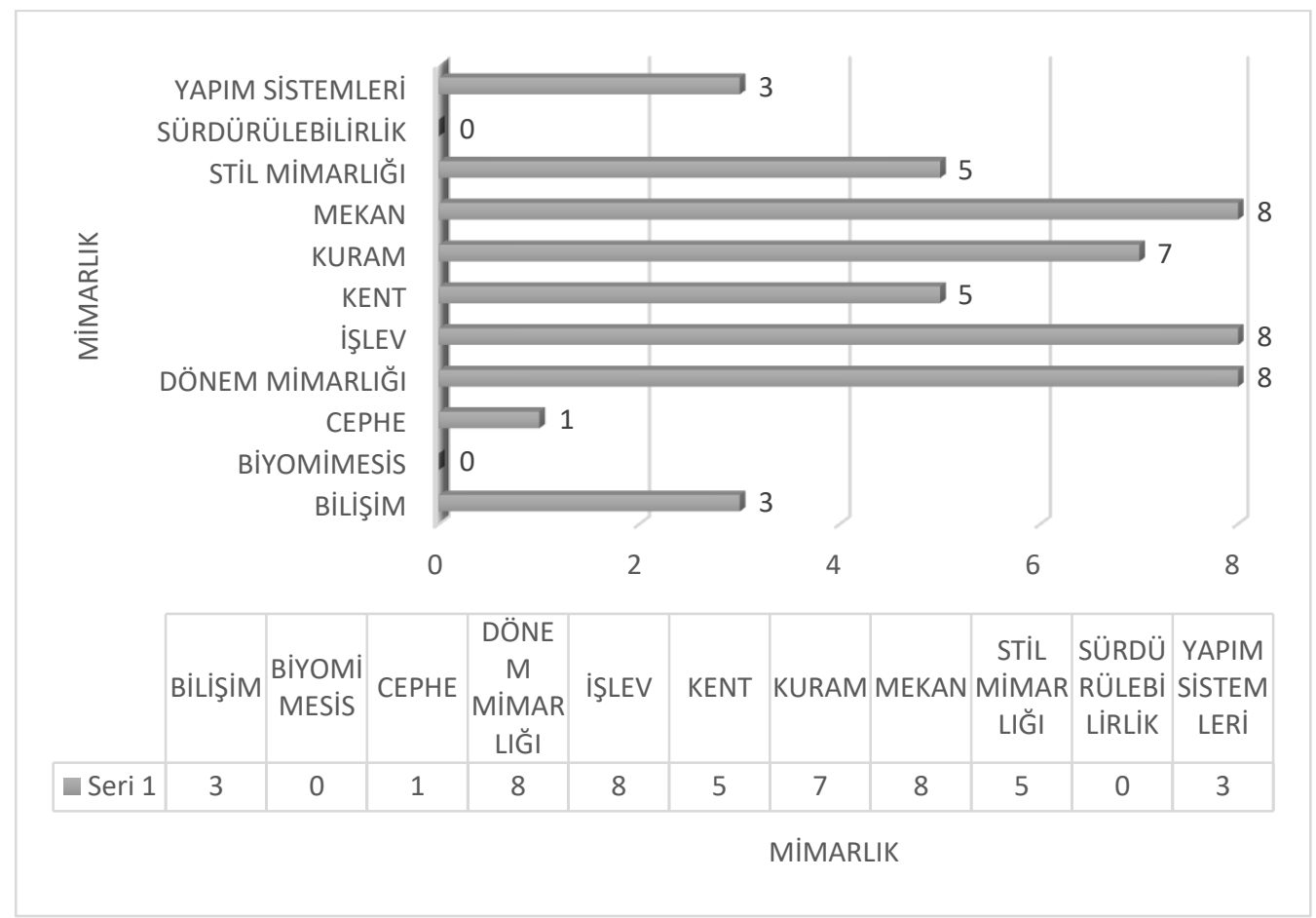

Tablo 4: 2000 öncesi tez çalışmalarının mimarlık konusunun alt başlıklarına göre dağılımı

Tablo 4'e göre mimarlık konusunun en fazla çalışıldığı konular 'dönem mimarlığı, işlev ve mekan' arasında dağılmaktadır. En az çalışılan konular ise 'cephe'dir. Tabloda yer alan biyomimesis, sürdürülebilirlik kavramları hiç çalışılmamıştır.

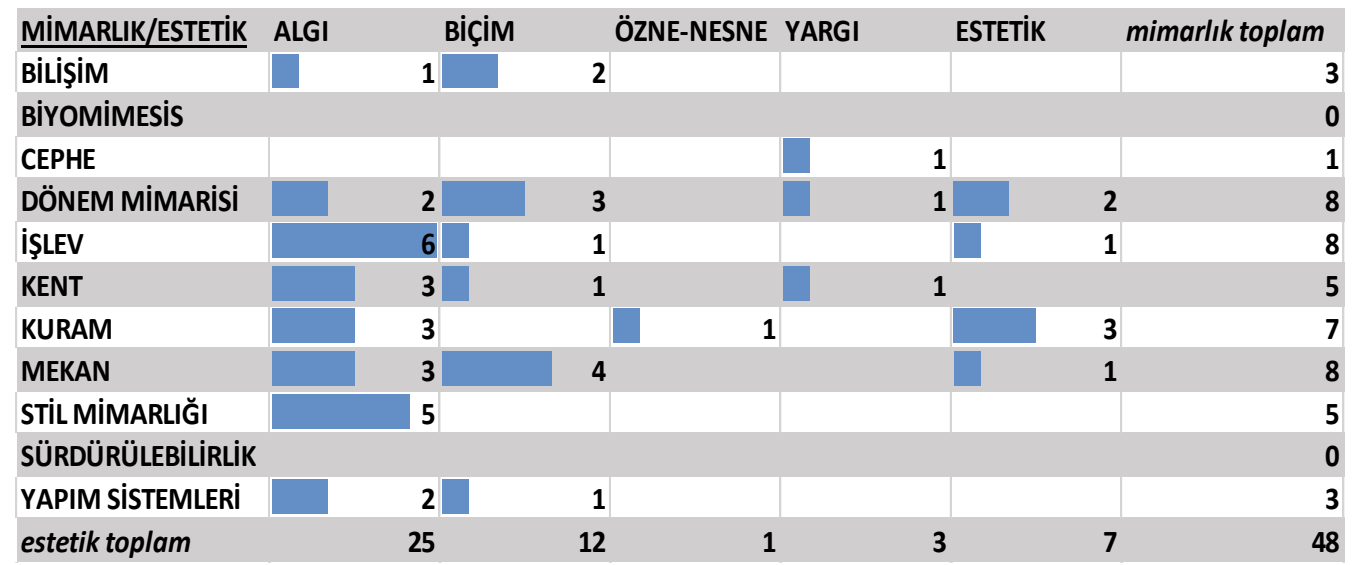

Tablo 5: Mimarlık alt başlıklarının, hangi estetik alt başlıkların ile çalışıldığının dağılımı

Tablo 5' e göre 2000 öncesi çalışılan tezler genellikle mimarlıktaki dönem, işlev ve mekan konuların estetiğin algı ve biçim alt başlıkları ile çalışılmıştır. Verilere göre en fazla eşleşme sağlayan konular işlev ve algıdır. Bu da 2000 öncesinde en 


\section{MIMARLIKTA ESTETİK DEĞERLENDİRME: ULUSAL TEZLER ÇERÇEVESINNDE SORGULAMA}

fazla çalışılan konunun işlev konusun algısı üzerine olduğunu göstermektedir. Sadece bir kez çalışılan cephe konusu yargı ile eşleşirken, yalnız bir kez çalışılan özne-nesne konusu da kuram ile eşleşiyor.

\section{0 'dan 2010'a}

Yapılan araştırma doğrultusunda 2000 senesi dahil olmak üzere 2010 senesine kadar 83 tez yayınlanmıştır. Tez sayı ve türlerinin gösterildiği tabloda 83 tezin tamamı dahil edilirmiş. Tez incelemelerinde 83 tezden 11'nin mimarlık ya da estetik ile ilgili olmadığı tespit edilmiştir. Dolasıyla mimarlık ve estetik başlıkları adı altında oluşturulan tablolarda 72 tez baz alınmıştır.

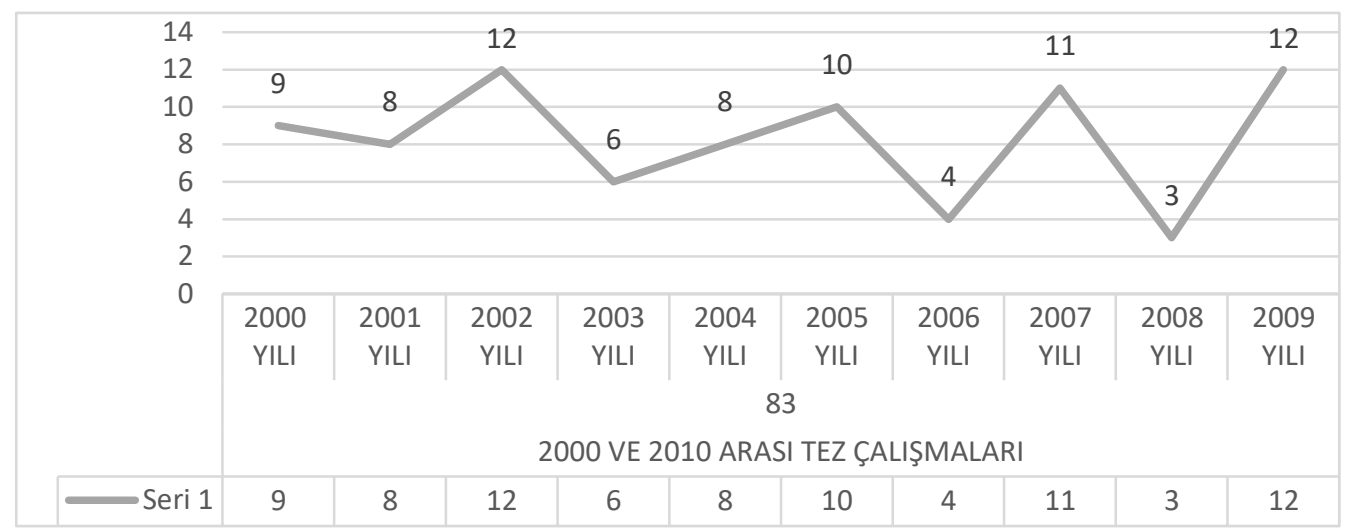

Tablo 6: 2000-2010 arası tez çalışmalarını yıllara göre dağılımları

2000-2010 arasında her sene tez estetik ve mimarlık ile ilgili tez üretilmiştir. Yıllara göre analiz edilen tez sayıların da en fazla yayın yapılan yılların 2002 ve 2009 seneleri olduğu dikkat çekmektedir. Tablo, genellikle az yayın yapılan yılın ardından daha fazla çalışma yapıldığı, fazla yayın yapılan yılın ardından da daha az yayın yapan yıldığı bir grafik çizmektedir. Tablo 6'ya göre en az yayın yapılan yıl ise 3 çalışma ile 2006 senesidir. 
MIMARLIKTA ESTETİK DEĞERLENDİRME: ULUSAL TEZLER ÇERÇEVESINNDE SORGULAMA

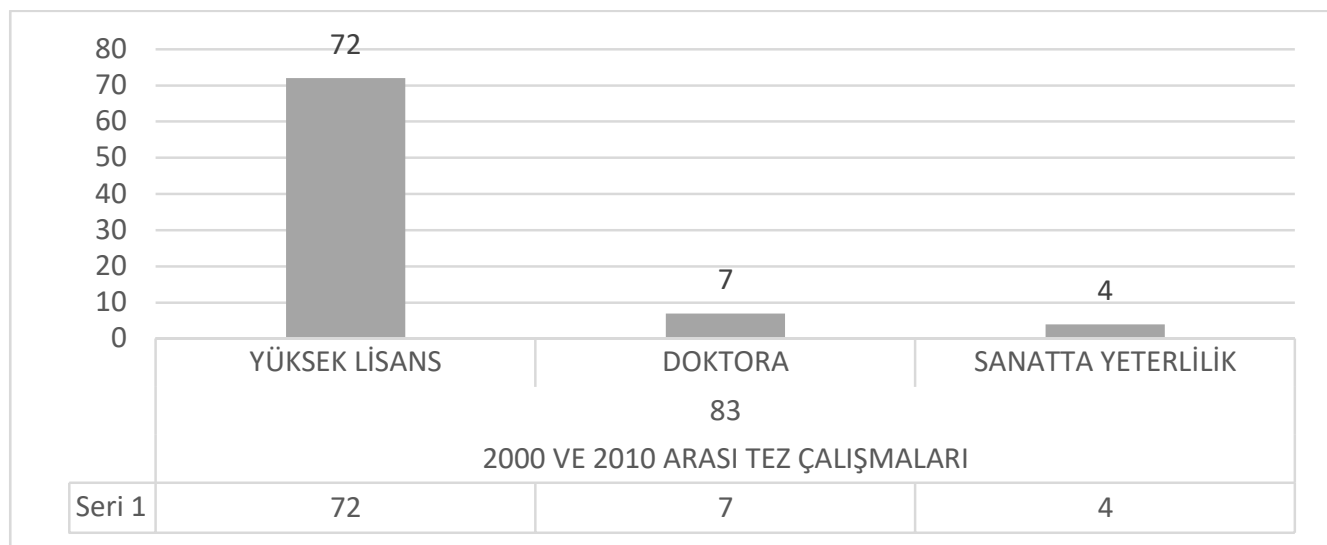

Tablo 7: 2000-2010 arası tez çalışmalarının türlerine göre dağılımı

2000 ve 2010 arası yayınlarda en fazla yayın yapılan tez türü 72 tez ile yüksek lisanstır. Bu durumu 7 tez ile doktora 4 tez ile sanatta yeterlilik takip etmektedir. Yüksek lisans tez sayısının daha fazla çalışılan tür olması 2000 öncesi ile benzerlik göstermektedir. Ancak doktora tez sayısında da bir düşüş söz konusudur. Yapılan inceleme doğrultusunda mimarlık ya da estetik ile ilgili olmayan 11 tezin tamamı yüksek lisans tezleridir.

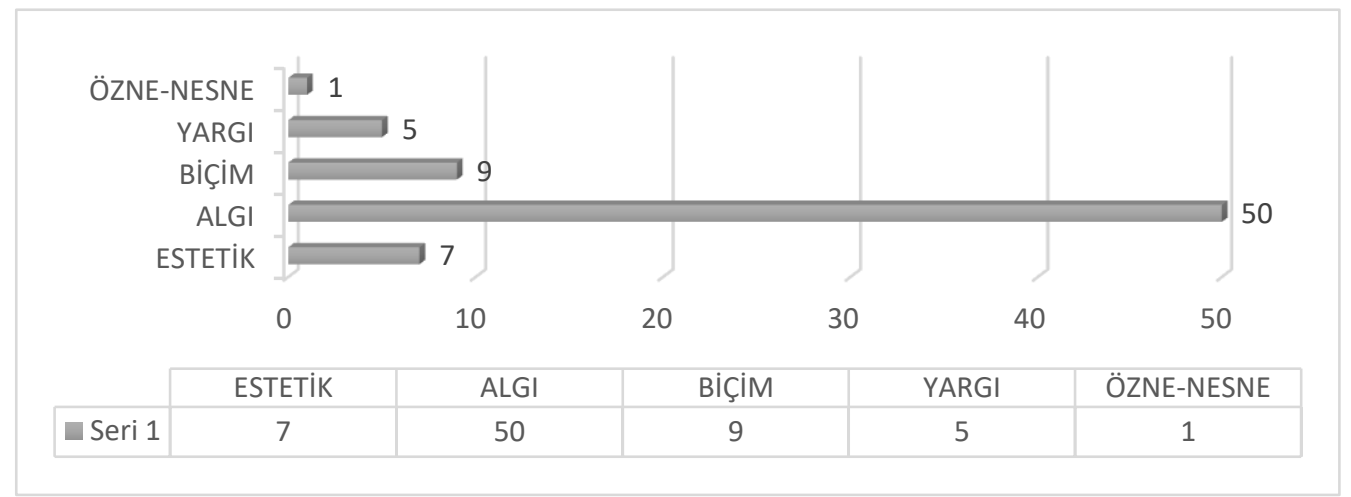

Tablo 8: 2000-2010 arası tezlerin estetik konusunun alt başlıklarına göre dağılımı

2000-2010 arası incelemeye alınan bu tabloda estetik konusu en fazla 50 tez ile alg1 alt başlığı ile ele alınmıştır En az ise 1 tez ile özne-nesne konusudur. 7 tez çalışması ise estetiği alt başlığa indirgemeyip konuyu bütün olarak ele almıştır. En fazla ve en az çalışılan konular 2000 öncesi ile paralellik göstermektedir. 


\section{MIMMARLIKTA ESTETIKK DEĞERLENDİRME: ULUSAL TEZLER}

ÇERÇEVESINNDE SORGULAMA

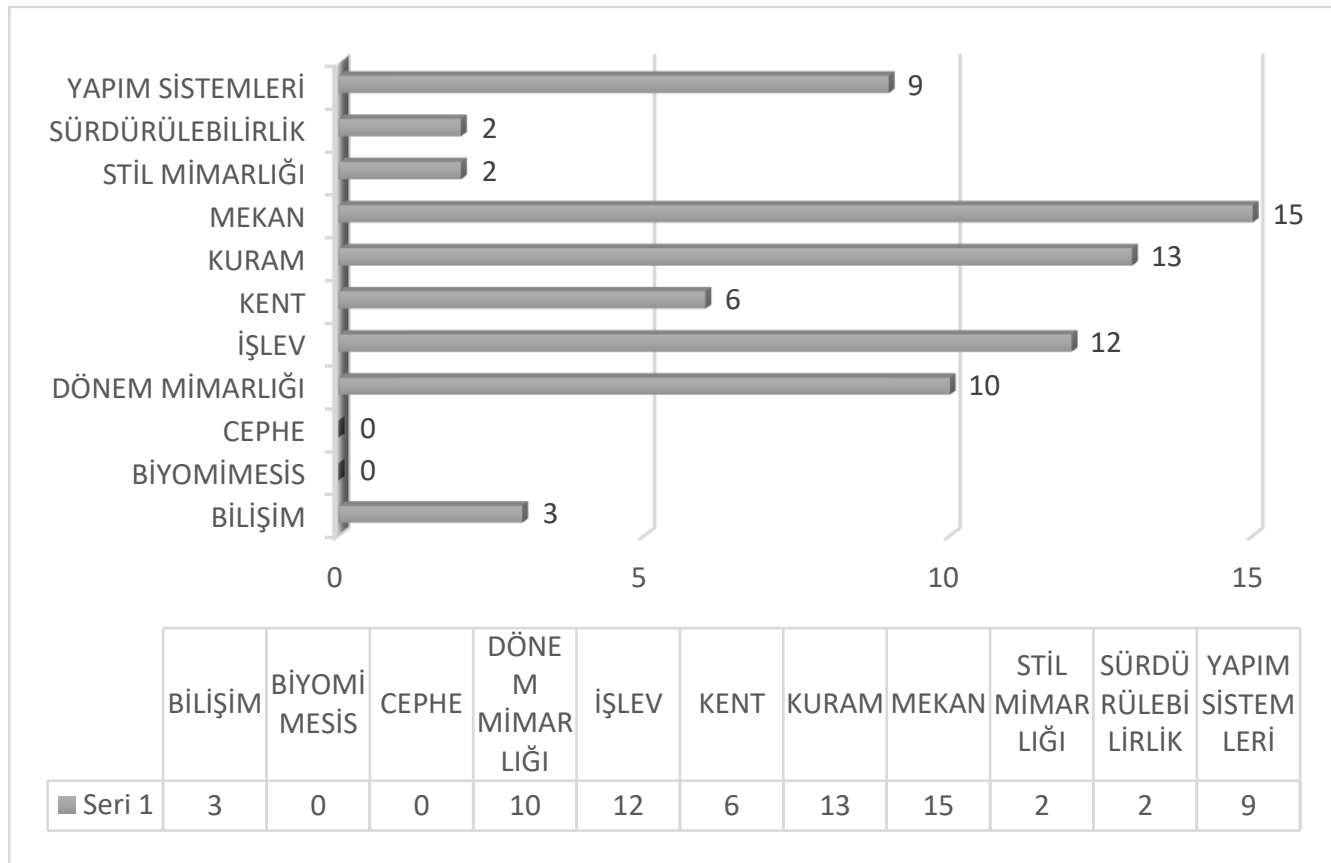

Tablo 9: 2000-2010 arası tez çalışmalarının mimarlık konusunu alt başlığına göre dağılımı

Tablo 9'a göre mimarlık konusunun en fazla çalışıldığı alt başlık 15 tez çalışması ile 'mekan'dır. Mekan konusunu, 13 çalışma ile 'kuram', 12 çalışma ile 'işlev' takip etmektedir. En az çalışılan konular ise 2'şer yayın ile 'sürdürülebilirlik' ve 'stil mimarlığı'dır. Cephe ve biyomimesis kavramıla ilgili çalışma yapılmamıştır. Sürdürülebilirlik kavramı ilk kez 2000 senesinde yüksek lisans tezi olarak karşımıza çıkmaktadır.

\begin{tabular}{|c|c|c|c|c|c|c|c|}
\hline MIMARLIK/ESTETIK & ALGI & віс̧ім & ÖZNE-NESNE & YARGI & ESTETIK & & mimarlık toplam \\
\hline BiLişim & D & 1 & 2 & & & & 3 \\
\hline \multicolumn{8}{|l|}{ BIYOMIMESIS } \\
\hline CEPHE & & & & & & & 0 \\
\hline DÖNEM MIMARISI & & 7 & 3 & & & & 10 \\
\hline işLEV & & 8 & & 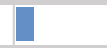 & 1 & 3 & 12 \\
\hline KENT & & 5 & & 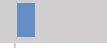 & 1 & & 6 \\
\hline KURAM & & 9 & D & & & 3 & 13 \\
\hline MEKAN & & 10 & 3 & & 1 & 1 & 15 \\
\hline STIL MIMARLIĞI & & 2 & & & & & 2 \\
\hline SÜRDÜRÜLEBiLIRLiK & t & 1 & 1 & & & & 2 \\
\hline YAPIM SISTEMLERI & & 7 & & & 2 & & 9 \\
\hline estetk toplam & & 50 & 9 & & 5 & 7 & 72 \\
\hline
\end{tabular}

Tablo 10: Mimarlık alt başlıklarının, hangi estetik alt başlıkları ile çalışıldığının dağılımı

Tablo 10' a göre en fazla eşleşme sağlayan alt başlıklar 10 tez ile 'mekan' ve 'algı' kavramlarıdır. Algı üzerine birçok çalışmanın bulunduğu bu 10 senelik 


\section{MIMMARLIKTA ESTETIKK DEĞERLENDİRME: ULUSAL TEZLER ÇERÇEVESİNDE SORGULAMA}

dilimde 'kuram' konusu da 9 tez sayısı ile en fazla çalışılan tez konusu olduğu söylenebilir. Algı konusun en az çalışıldığı mimarlık konusu ise 1'er tez ile 'bilişim' ve 'sürdürülebilirlik' tir. Algı konusundan sonra en fazla çalışılan alt başlık ise 9 tez ile 'biçim'dir. Biçim ile en fazla çalışılan konu yine 'mekan'dır. Ancak dönem mimarisi de biçim konusunu en fazla çalışıldığını alanlardan biridir.

\section{0'dan günümüze}

Yapılan araştırmaya göre 2010 senesinden günümüze olan tez sayısı 177'dir. Bu kapsam içerisinde başlangıç senesi olan 2010 yılı ve çalışma dönemine yakın bir sene olan 2021 yılı dahil edilmiştir. Tez sayıların ve türlerinin çizildiği tablolarda 177 tezin tamamı dahil edilmiştir. Ancak yapılan tez incelemelerinde bu tezlerden 26 tanesinin mimarlık ve ya estetik ile ilgili olmadığ 1 tespit edilmiştir. Dolayısıyla estetik ve mimarlık konu başlıklarının altında çizilen tablolarda incelemeye alınan tez sayıs1 151'dir.

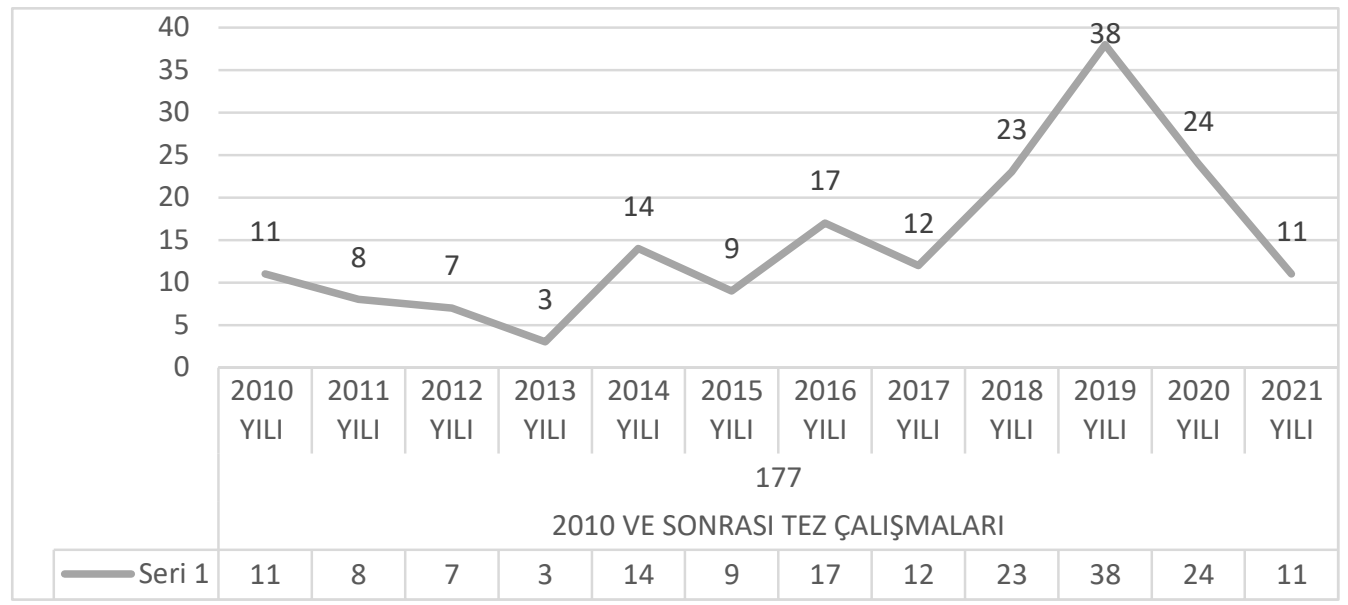

Tablo 11: 2010 ve sonrası tez çalışmalarının yıllara göre dağılımı

Tablo 11'e bakıldığında istikrarlı bir yükseliş söz konusu olmasa da en fazla yayın yapılan yıl 38 tez ile 2019 senesi, en az yayın yapılan yıl ise 3 yayın ile 2013 'tür. 2019 senesinde yapılan çalışmaların çoğu yüksek lisans tez çalışması iken 2013 senesin de en fazla çalışılan tez türü ise doktoradır. 
MIMARLIKTA ESTETIK DEĞERLENDİRME: ULUSAL TEZLER ÇERÇEVESİNDE SORGULAMA

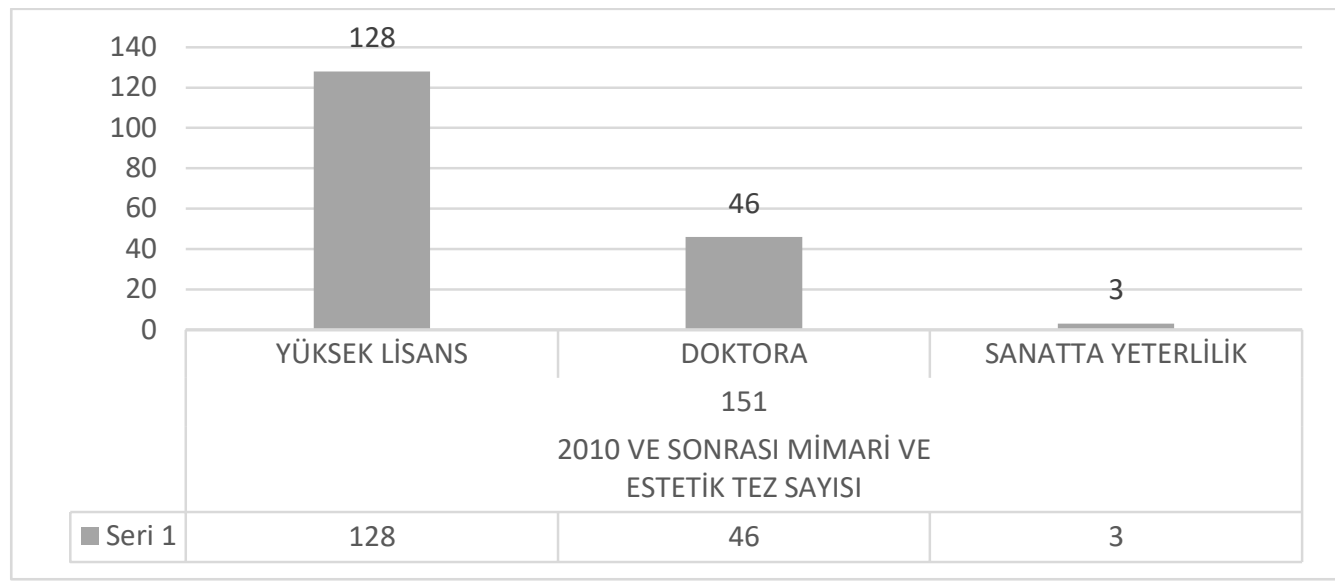

Tablo 12: 2010 ve sonrası tez çalışmalarının yayın türüne göre dağılımı

Tablo 12'ye göre 2010 senesi ve sonrasında yayınlana tezlerin 177 tanesini 128 'i yüksek lisans tezi, 46 'sı doktora tezi ve $3^{\prime}$ ü sanatta yeterlik alanındadır. Buna göre estetik konusun mimarlık disiplini içinde en fazla çalışıldığı tez türünün yüksek lisans olduğu söylenebilir. Mimarlık veya estetik disiplini içinde çalışılmayan 24 tezin 17 'si yüksek lisans, $7^{\prime}$ si doktora ve 2 'sinin sanatta yeterlilik tezi olduğu tespit edilmiştir.

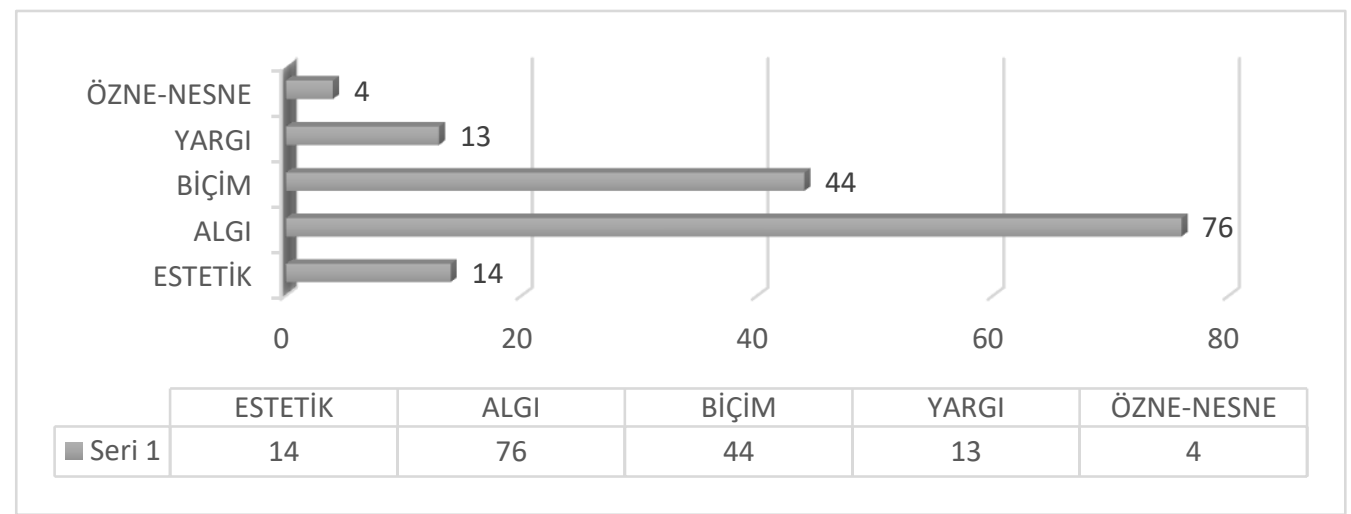

Tablo 13: 2010 ve sonrası tez çalışmalarının estetik konusunu alt başlığına göre dağılımı

Tablo 13'ye göre 2010 ve sonrası yayınların estetik alt başlık dağılımına bakıldığında en fazla çalışmanın yapıldığının alanın algı konusu üzerine, en az çalışmanın ise özne-nesne üzerine olduğunu görmekteyiz. Tablonun sonuçlarına göre 14 tezin ise estetik konusunu alt başlığına indirgemeden konuyu bir bütün olarak ele aldığı görülmektedir. En az ve en fazla çalışılan konuların dağılımı 20002010 arası konu dağılımıyla paralellik göstermektedir. 


\section{MIMMARLIKTA ESTETIKK DEĞERLENDİRME: ULUSAL TEZLER}

ÇERÇEVESINNDE SORGULAMA

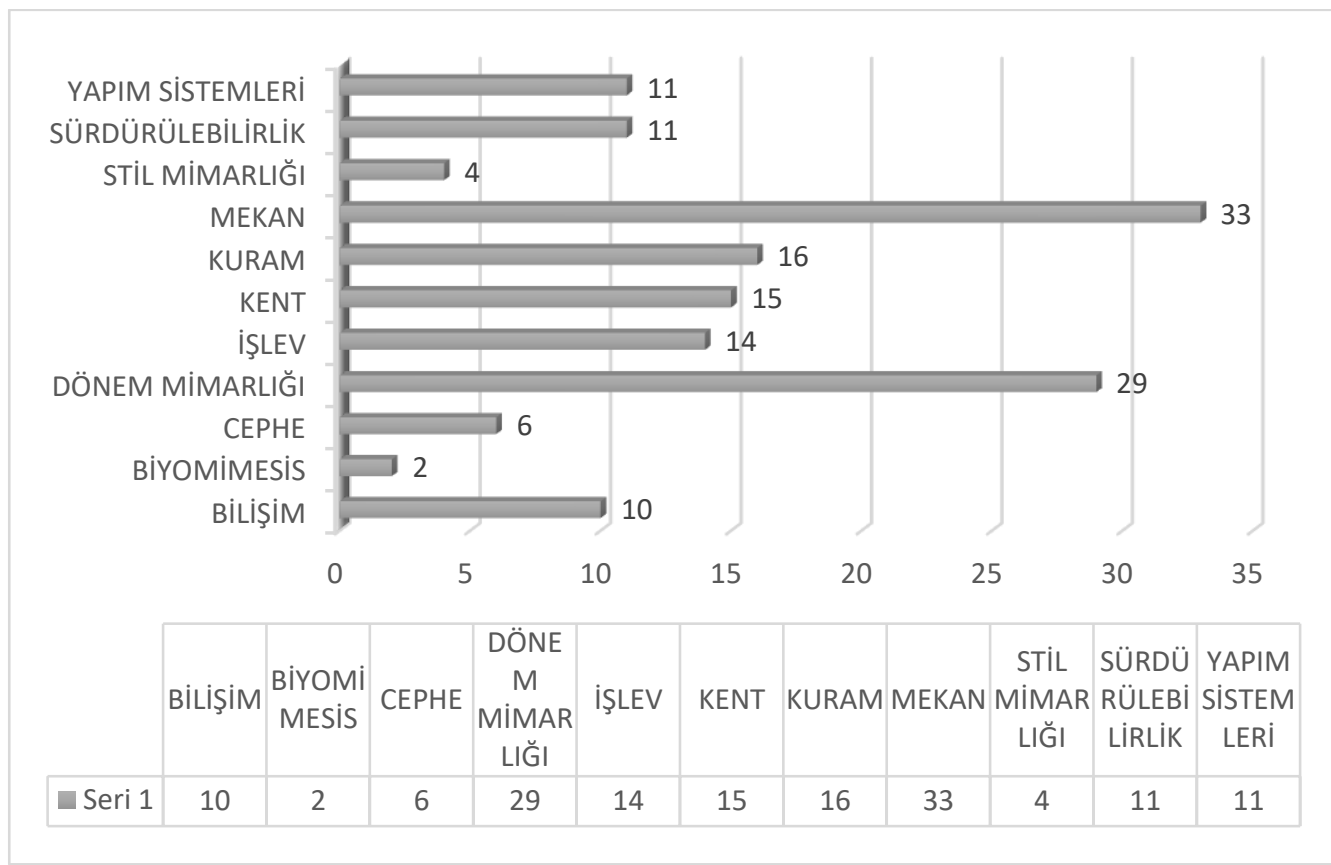

Tablo 14: 2010 ve sonrası tez çalışmalarının mimarlık konusunu alt başlığına göre dağılımı

Tablo 14'e göre mimarlık konusunun en fazla çalışıldığı alt başlık 'mekan'dır. Mekan konusu üzerine 33 çalışma bulunurken 29 çalışma ile 'dönem mimarlığı' onu takip etmektedir. En az çalışılan konular ise 2 yayın ile, 2000 öncesi tez çalışmalarında görmediğimiz, 'biyomimesis' kavramı ve 4 tez çalışması ile 'stil mimarlığı' dır. Biyomimesis kavramına bilişim başlığı altında ilk kez 2014 senesinde bir doktora tezi olarak karşımıza çıkmaktadır.

\begin{tabular}{|c|c|c|c|c|c|c|c|}
\hline MIMARLIK/ESTETIK & ALGI & віс̧ім & ÖZNE-NESNE & YARGI & ESTETIK & & mimarlık toplam \\
\hline Bíiş̧iM & & 2 & 4 & & 2 & & 10 \\
\hline BIYOMIMESIS & & 1 & & & & 1 & 2 \\
\hline CEPHE & & 3 & 1 & & 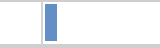 & 1 & 6 \\
\hline DÖNEM MIMARISI & & 14 & 13 & 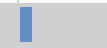 & 1 & 1 & 29 \\
\hline işLEV & & 6 & 5 & & & 3 & 14 \\
\hline KENT & & 7 & 3 & 1 & 3 & 1 & 15 \\
\hline KURAM & & 10 & 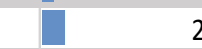 & 2 & 1 & 3 & 16 \\
\hline MEKAN & & 9 & 11 & 1 & 3 & 2 & 33 \\
\hline STIL MIMARLIĞI & & 4 & & & & & 4 \\
\hline SÜRDÜRÜLEBILIIRLiK & & 4 & 3 & & 3 & 1 & 11 \\
\hline YAPIM SISTEMLERI & & 6 & 4 & & 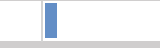 & 1 & 11 \\
\hline estetk toplam & & 76 & 44 & 4 & 13 & 14 & 151 \\
\hline
\end{tabular}

Tablo 15: Mimarlık alt başlıklarının, hangi estetik alt başlıkları ile çalışıldığının dağılımı

Tablo 15'e göre mimarlığın alt konusu olan 'dönem mimarisi' ve 'mekan' kavramının, estetik alt konusunun 'algı' ve 'biçim' kavramılla en fazla çalışıldığı 


\section{MIMMARLIKTA ESTETIKK DEĞERLENDİRME: ULUSAL TEZLER ÇERÇEVESİNDE SORGULAMA}

dikkat çekmektedir. En fazla çalışılan konular 2000 öncesi tez çalışmalarıyla benzerlik göstermektedir. Geçmiş dönemde var olan yapılar ya da akımların algısal ve biçimsel analizlerin genellikle yapıldığı bu aralıkta aynı zamanda 'mekan' kavramı da irdelenmiştir. Yine çalışma sayısının azımsanmayacak seviyede artığını söyleyebileceğimiz 'kuram' kavramı da genellikle 'algı' üzerine çalışılmıştır.

\section{Total Analiz ve Sonuç}

Totalde 1984 senesinde başlayıp günümüze kadar yazılmış olan 312 tane tezin, 241 tanesi yüksek lisans, 62 tanesi doktora, 9 tanesi de sanatta yeterlilik alanındadır. Yapılan araştırmaya göre bu tezlerden 31 tanesi yüksek lisans, 8 tanesi doktora ve 2 tanesi sanatta yeterlilik olan toplamdaki 41 tezin mimarlık ya da estetik ile ilgili olmadığ 1 tespit edilmiştir. Bu durumda 210 tanesi yüksek lisans, 54 tanesi doktora, 7 tanesi sanatta yeterlilik olan toplamdaki 271 tez mimarlık ve estetik ile ilgilidir. Tüm zamanların en fazla yayın yapılan yılı 31'i yüksek lisans, $7^{\prime}$ si doktora olan 38 tez sayısı ile 2019 senesidir.

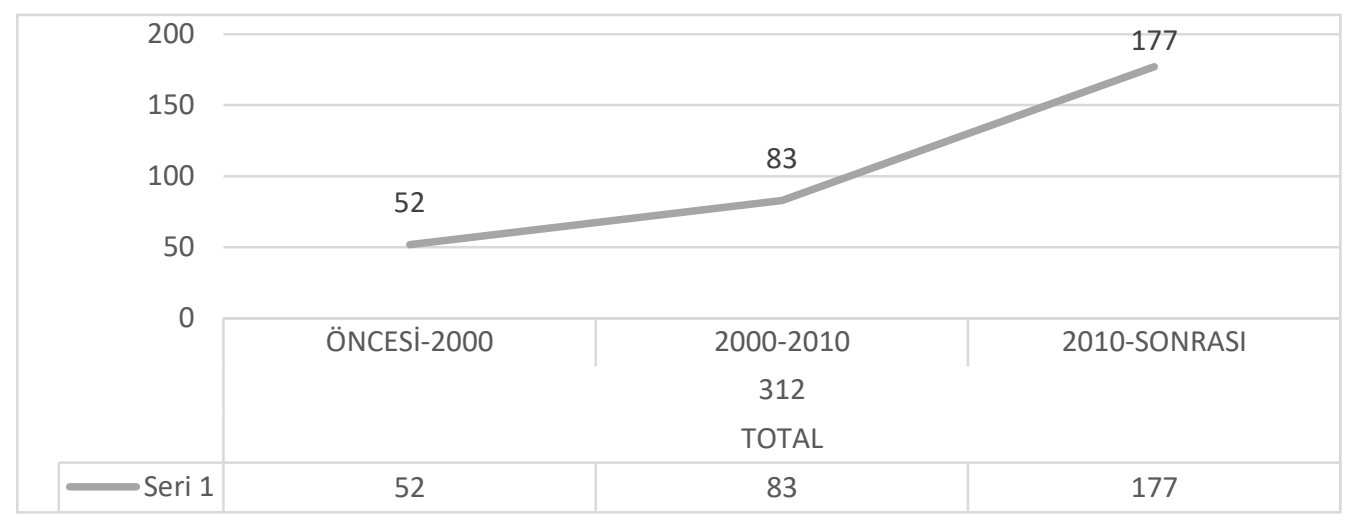

Tablo 16: Tez çalışmalarının yıllara göre dağılımı

Tablo 16'daki grafikte görüldüğü gibi her 10 senelik dilimde çalışma sayılarında istikrarlı bir artış görülmektedir. Ancak bu istikrarlı yükseliş doktora tezleri için geçerli değildir. 2000 öncesi yayınlanan doktora tez sayısı 2000 - 2010 arası yayınlanan tez sayısından fazladır. 
MIMMARLIKTA ESTETİK DEĞERLENDİRME: ULUSAL TEZLER

ÇERÇEVESINNDE SORGULAMA

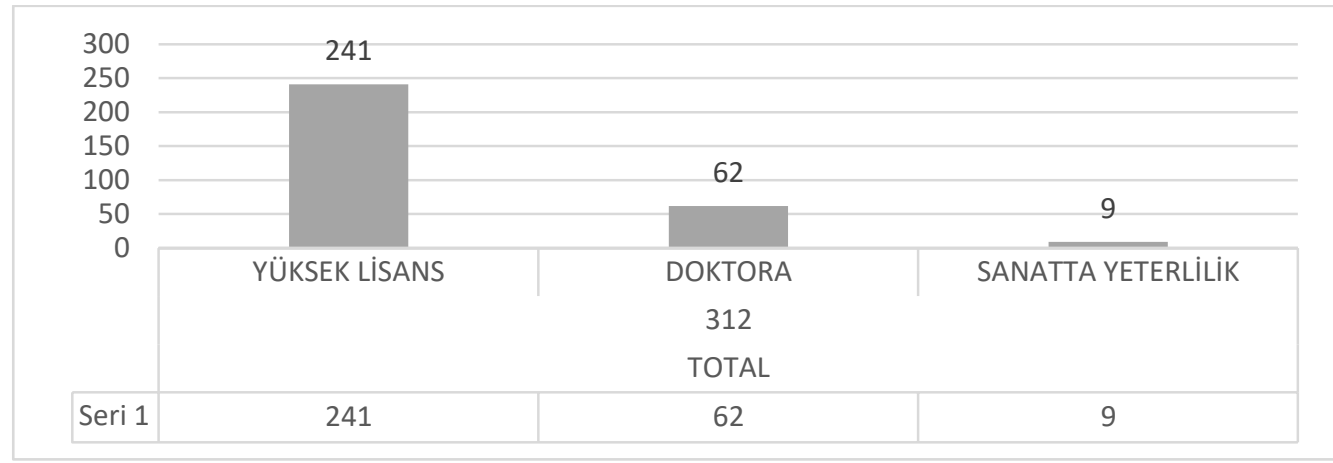

Tablo 17: Tez çalışmalarının türlerine göre dağılımı

Üretilen tezlerde yüksek lisans tez türü en fazla çalışılan türdür. Yüksek lisans tez sayılarının doktora tez sayıları oranına baktığımızda, oranı en fazla olan sene aralığ1 2000 - 2010 iken, en az olan 2010 senesinden günümüze olan aralıktır. Dolayısıyla doktora tez sayısının en fazla olduğunu gördüğümüz 2010 - günümüz aralığında yüksek lisans tez sayısına oranla daha az çalışıldığı söylenebilir.

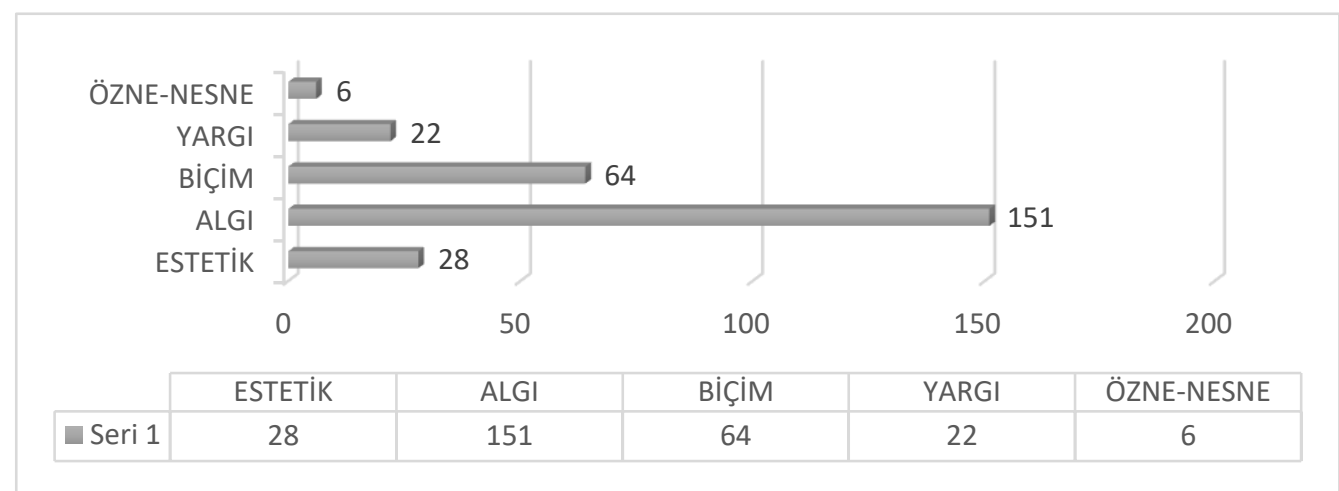

Tablo 18: Tez çalışmalarının estetik konusunun alt başlıklarına göre dağılımı

Yukardaki grafiğe göre totalde en fazla çalışılan konu 151 tez ile algıdır. Tüm dönem aralığında benzerlik gösteren bu dağılımda totalde en az çalışılan konunun özne-nesne üzerine olduğu söylenebilir. Algı kavramından sonra en fazla çalışma yapılan konusu biçimsel analizler üzerinedir. 28 tez çalışması ise herhangi bir alt başlığa indirgemeden estetik konusunu genel bir yaklaşım içinde ele aldığı kabul edilmiştir. 


\section{MIMMARLIKTA ESTETIKK DEĞERLENDİRME: ULUSAL TEZLER ÇERÇEVESİNDE SORGULAMA}

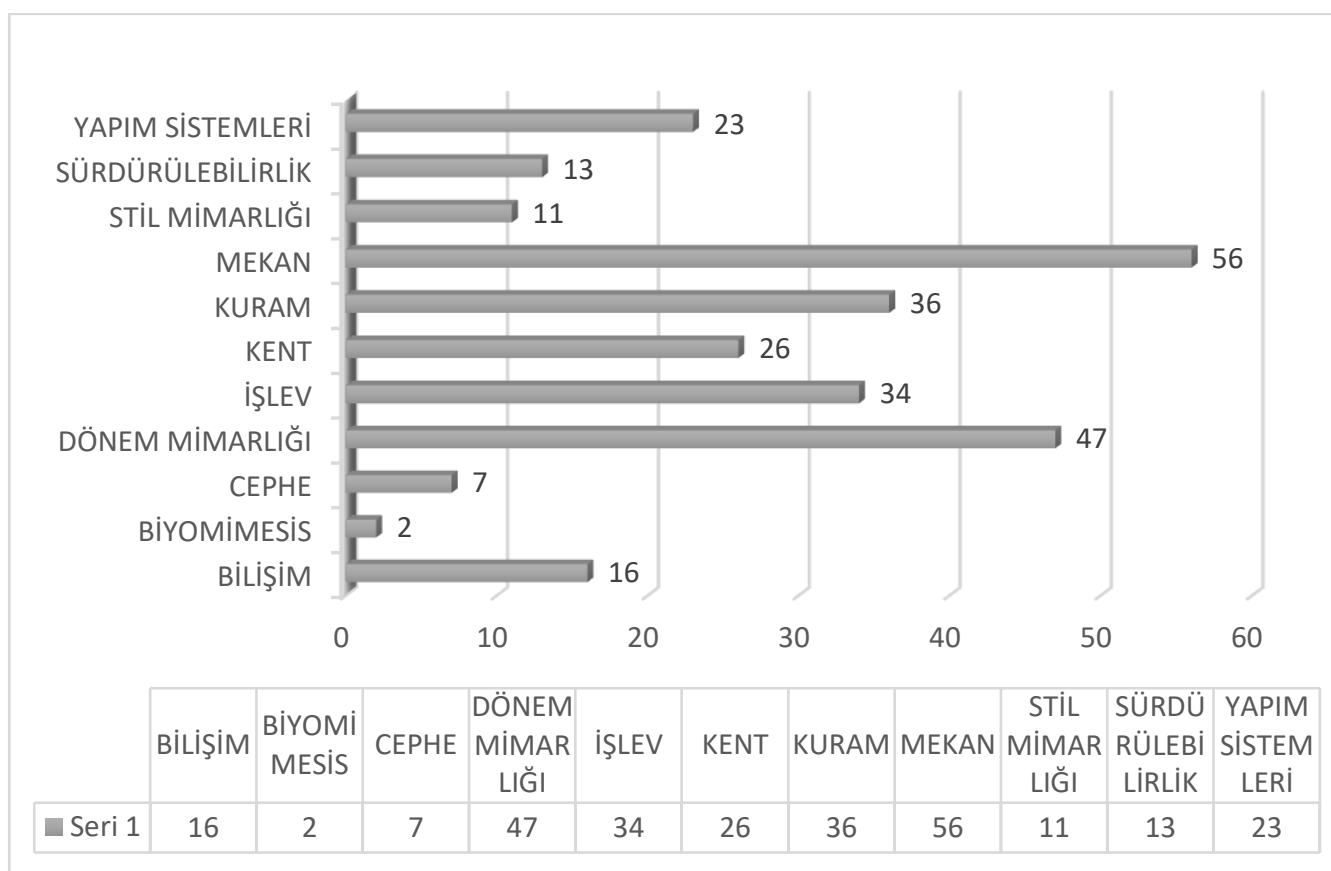

Tablo 19: Tez çalışmalarının mimarlık konusunun alt başlıklarına göre dağılımı

Total verilere bakıldığında en fazla çalışmaya konu olan 'mekan' kavramı her dönem aralığında en fazla çalışma yapılan konudur. En az çalışılan konusu ise mimarlık camiası içinde yeni olan 'biyomimesis' kavramıdır. Mekan kavramını sadece 3 tez eksik ile 'dönem mimarlığı' takip etmektedir. Tablo sonuçlarına göre geçmiş dönemlerde yapılan mimari çalışmaların estetik analizleri yoğun bir şekilde çalışıldığı söylenebilir. Mekan ve dönem mimarlığından sonra 'işlev' ve 'kuram' kavramlarının çalışıldığı görülmektedir. Biyomimesisten sonra daha sı̆̆ çalışılan konunun 'cephe' olduğu görülmektedir.

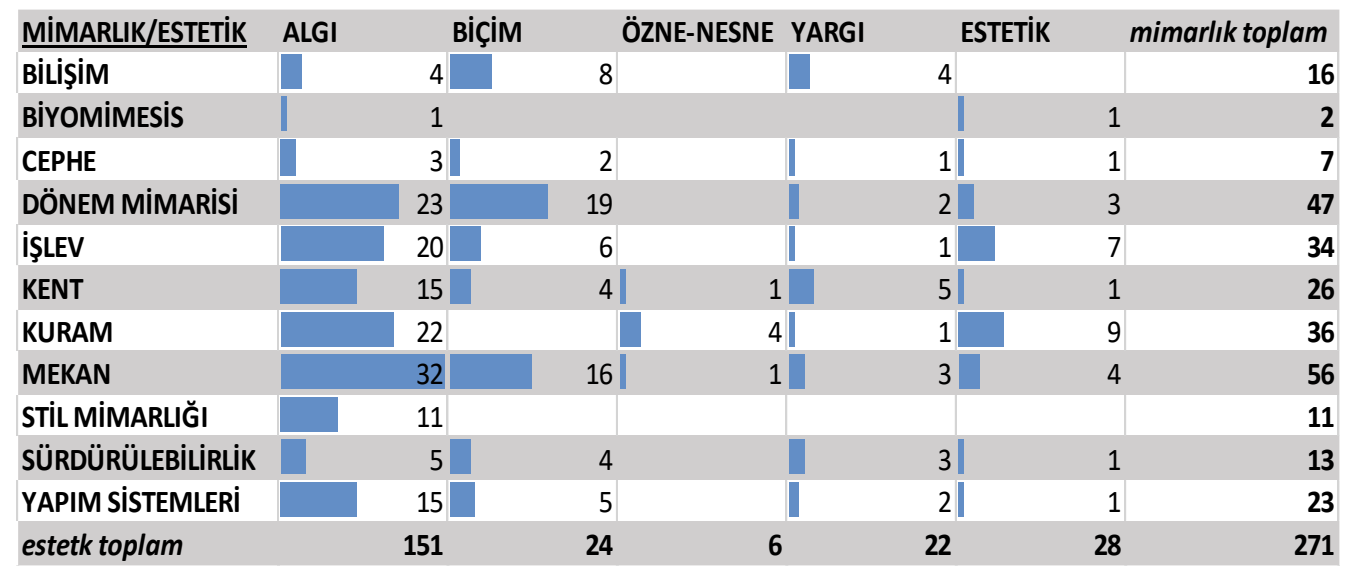

Tablo 20: Mimarlık alt başlıklarının estetik alt başlıkları ile eşleşmesi 


\section{MIMMARLIKTA ESTETIKK DEĞERLENDİRME: ULUSAL TEZLER ÇERÇEVESINDE SORGULAMA}

Total verilere bakıldığında algı konusunun nerdeyse her konu başlığı altında yoğun bir şekilde çalışıldığı görülmektedir. Her dönem aralığında olduğu gibi mimarlık disiplini içinde estetik konusunun en fazla irdelendiği alan 'mekan' konusudur. Dolasıyla mekan algısına etki eden su, ses gibi duyumsal verilerin algısı üzerine çalışmaların yoğun bir şekilde yapıldığı söylenebilir. Biçim analizi üzerine çalışma yapan araştırmacılar genellikle 'dönem mimarisi' ve 'mekan' konusu üzerine irdeleme yapmıştır. Buna göre dönem mimarlığı ve mekan kavramında etkili olan form, renk, 1şık, gibi biçimsel terimlerin analiz edildiği söylenebilir.

Biyomimesis, sürdürülebilirlik gibi son dönemlerde ortaya çıkan konular ise en az çalışılan konulardandır. Stil mimarlığı altında adına en fazla çalışma yürütülen mimar 'Tadao Ando' olması da dikkat çekmektedir. Yukardaki tabloya göre mimarlık disiplini altında olan ancak burada yer almayan konularla ilgili tez çalışması yapılmadığı söylenebilir.

Sürdürülebilirlik ve biyomimesis gibi dünya içinde yeni olan bazı konuların mimarlık disiplini içinde estetik irdelenmesinin yapılması, gelişen bilim ve teknolojiden mimarlığında etkilendiğini ve yeni alt başlıklar doğurduğuna bir örnektir.

Tablonun sunduğu verilerden biri de ulusal tez platformunda, mimari alt başlıklara indirgediğimiz bu alanların dışında kalan konuların henüz estetik bir analizinin yapılmadığı ya da yoğun olmadığı söylenebilir.

\section{KAYNAKÇA}

Becerik, Burçin, (2001), Mimarlıkta estetik olgusu ve değerlendirmesi sorunu, İstanbul Teknik Üniversitesi Fen Bilimleri Enstitüsü, İstanbul.

Eaton, M.M. (1995) . 'The Social Construction Of Aesthetic Response'. British Journal of Aesthetics, 35/2, s.95-107.

Ergün, M. (2020). Eğitim Felsefesi. (Ed. Ergün, M., Çoban, A.), Ankara: Pegem Akademi Yayınları.

Ergün, M. (2019). Estetik (Sanat Felsefesi). Ankara: Pegem Akademi Yayınları.

Erş, İ.(2005). 'Estetik Üzerine Derlemeler' Us düşün ve ötesi: estetik sorunu dergisi, 9. sayı.

URL: http://www.dusunuyorumdergisi.com/estetik-uzerine-derlemeler/ Son Erişim Tarihi: 13.03 .2021

Hasol, D. (1979). Ansiklopedik Mimarlık Sözlü̈̆ü. İstanbul: Yapı Endüstri Merkezi Yayınları.

İnternet: Youtube.com, Sayın, N. MiM. Trt2. URL: https://www.youtube.com/watch?v=38VfR-oveDM\&ab_channel=TRT2 Son Erişim Tarihi: 13.03.2021

İnternet: Yöktez, URL: https://tez.yok.gov.tr/UlusalTezMerkezi/ Son Erişim Tarihi: 20.10.2021

Kuban, D. (2002). Mimarlık Kavramları. İstanbul: Yem Yayınları.

Uluslararası Sanat ve Estetik Dergisi Y1l: 4, Sayı: 7, Aralık 2021 


\section{MIMMARLIKTA ESTETİK DEĞERLENDİRME: ULUSAL TEZLER ÇERÇEVESINNDE SORGULAMA}

Masiero, R. (2006). Mimaride estetik. Ankara: Dost Kitabevi.

Pollio, Vitruvius. (2005). Mimarlk Üzerine On Kitap. İstanbul: Şevki Vanlı Mimarlık Vakfı.

Selçuk, S. A.: Sorguç, A. G., (2007). 'Mimarlık tasarımı paradigmasında biomimesis'in etkisi', Gazi Üniv. Müh. Mim. Fak. Der. 22/2, s.451-459.

Tekel, A. (2015). 'Estetik yarg1 ve estetik yargıyı etkiyen faktörler', Sanat ve Tasarm Dergisi, s. 149-157.

Timuçin, A. (2017). Estetik. İstanbul: Bulut Yayınları.

Tunalı, İ. (1998). Estetik. İstanbul: Remzi Kitapevi.

Yılmaz, İrem, (2018), Çağdaş mimaride estetik kavramı ve tüketim kültürüyle ilişkisinin otel yapıları üzerinden incelenmesi, Mimar Sinan Güzel Sanatlar Üniversitesi Fen Bilimleri Enstitüsü, İstanbul.

Yücel, Çiğdem, (2011). Ekolojik yapı estetik ilişkisinin deneysel olarak irdelenmesi, Gazi Üniversitesi Fen Bilimleri Enstitüsü, Ankara. 